\title{
Infarct tissue characteristics of patients with versus without early revascularization for acute myocardial infarction: a contrast enhancement cardiovascular magnetic resonance imaging study
}

Marlon A Olimulder*, Karin Kraaier, Michel A Galjee, Marcoen Scholten, Jan van Es, Lodewijk Wagenaar, Job van der Palen, Clemens von Birgelen

From 2011 SCMR/Euro CMR Joint Scientific Sessions Nice, France. 3-6 February 2011

\section{Introduction}

Histopathological studies suggested that early revascularization for acute myocardial infarction (MI) limits size, transmural extent, and homogeneity of myocardial necrosis. However, the long-term effect of early revascularization on infarct tissue characteristics is greatly unknown. Cardiovascular magnetic resonance (CMR) imaging with contrast enhancement (CE) allows noninvasive examination of infarct tissue characteristics and left ventricular (LV) dimensions and function in one examination.

\section{Purpose}

In a consecutive series of patients with prior MI in whom CE-CMR was performed for clinical reasons, we compared data from patients with versus without early revascularization for acute MI. Based on the findings of previous histopathological studies, we hypothesized that in patients with early revascularization, infarct areas may be smaller, less homogeneous, and less transmural on CE-CMR than in patients without early revascularization.

\section{Methods}

A total of 86 patients, referred for cardiac evaluation for various clinical reasons, were examined with CE-CMR $>1$ month (median 11, range 1-425) post-acute MI. We compared patients with $(n=44)$ versus without $(n=42)$ successful early revascularization for acute MI. CineCMR measurements included left ventricular (LV) end-

MST Enschede, Enschede, Netherlands diastolic and end-systolic volumes, LV ejection fraction (LVEF,\%), and wall motion score index (WMSI). CE images were analyzed for core, peri, and total infarct size (\%), and for the number of transmural segments.

\section{Results}

Patients with successful early revascularization had a better LVEF ( $41 \pm 18$ vs. $33 \pm 14 \%$; $\mathrm{P}=0.02$ ), a superior WMSI (1.12, range $0.00-2.76$ vs. 1.42 , range $0.00-3.00$;

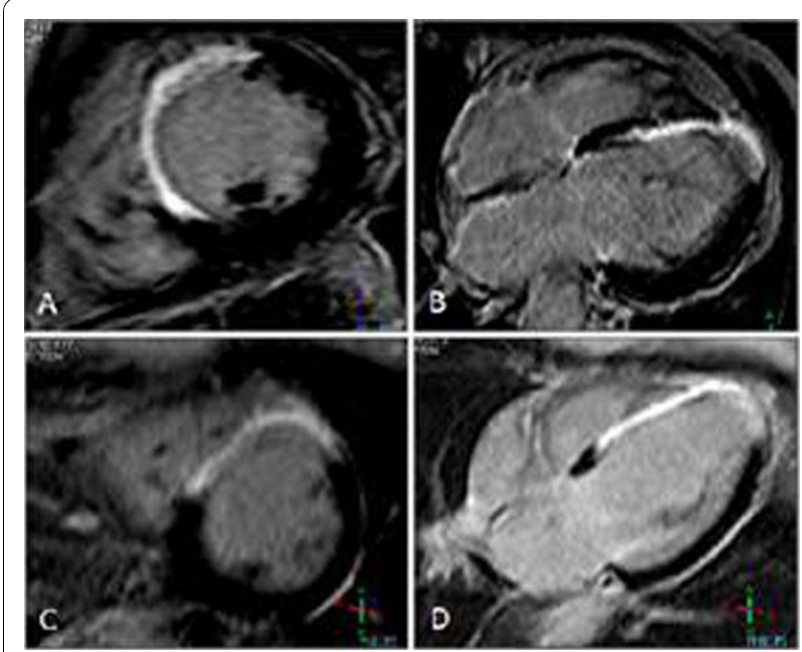

Figure $1(A, B) C E-C M R$ imaging short axis and four chamber view in an early revascularized patient, presence of transmural $C E$ is observed anteroseptal and apical. (C,D) CE -CMR imaging short axis view and four chamber view in a patient without early revascularization; presence of transmural CE is observed anteroseptal and apical. 
$\mathrm{P}=0.02)$, and smaller end-systolic volumes $(142 \pm 79$ vs. $179 \pm 94 ; \mathrm{P}=0.05)$ than patients without early revascularization. However, neither groups showed a difference in core ( $10 \pm 6$ vs. $10 \pm 6 \%)$, peri $(10 \pm 4$ vs. $10 \pm 4 \%)$, and total infarct size ( $20 \pm 10$ vs. $20 \pm 9 \%)$, or transmural extent ( $P>0.30$ for all). Figure 1.

\section{Conclusion}

Long-term survivors of acute MI with versus without successful early revascularization showed no difference in infarct tissue characteristics as assessed by CE-CMR. Nevertheless, LV

function was significantly lower in patients without early revascularization, who also tended to show other signs of LV remodelling.

Published: 2 February 2011

doi:10.1186/1532-429X-13-S1-P145

Cite this article as: Olimulder et al.: Infarct tissue characteristics of patients with versus without early revascularization for acute myocardial infarction: a contrast enhancement cardiovascular magnetic resonance imaging study. Journal of Cardiovascular Magnetic Resonance 2011 13(Suppl 1):P145.
Submit your next manuscript to BioMed Central and take full advantage of:

- Convenient online submission

- Thorough peer review

- No space constraints or color figure charges

- Immediate publication on acceptance

- Inclusion in PubMed, CAS, Scopus and Google Scholar

- Research which is freely available for redistribution

Submit your manuscript at www.biomedcentral.com/submit
C Biomed Central 